\title{
Evidence of diverse movement strategies and habitat use by white sharks, Carcharodon carcharias, off southern Australia
}

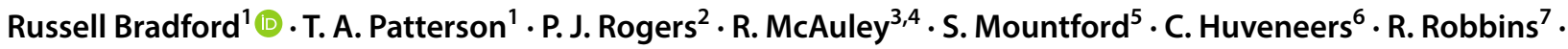 \\ A. Fox ${ }^{7} \cdot$ B. D. Bruce ${ }^{1}$
}

Received: 15 September 2019 / Accepted: 25 May 2020 / Published online: 4 June 2020

(c) The Author(s) 2020

\begin{abstract}
Large endothermic pelagic sharks are highly migratory and use habitats spanning a broad range of coastal, neritic and oceanic areas. This study aimed to resolve the current lack of information on the movements and habitat use of white sharks, Carcharodon carcharias, between shelf, slope and oceanic areas located off southwestern Australia. Movement behaviours, spatial distribution patterns and vertical habitat use of juvenile, sub-adult and adult white sharks ranging in size from 1.9 to $5.7 \mathrm{~m}$ total length were examined using 43 satellite tags deployed over 15 years. Pop-up satellite archival tags and satellitelinked radio tags collected 3663 days and $>109,900 \mathrm{~km}$ of tracking data over periods of up to 381 days. We demonstrated sex-based differences in movement and distribution patterns of male (21) and female (19) white sharks. Female dispersal was broader and extended further offshore than males, which largely remained in neritic and gulf habitats. Female white sharks experienced a narrower range of water temperatures $\left(F=9.0-19.0^{\circ} \mathrm{C} ; M=10.4-24.8^{\circ} \mathrm{C}\right)$. Despite these subtle differences, both sexes showed an affinity to the Neptune Island Group and the shelf slope canyons of the eastern Great Australian Bight, which are productive and oceanographically complex regions that support known prey of white sharks. This study highlighted that the southern-western Australian population of white sharks use off-shelf habitat to a greater extent than previously identified. Findings have potential implications for: ecological risk assessments of fisheries that operate in these offshore habitats and for monitoring and managing marine protected areas.
\end{abstract}

\section{Introduction}

Understanding the variability in movement strategies of marine predators at individual, ontogenetic and population levels is pivotal in assessing the relative risks of

Communicated by S. Hamilton.

Reviewed by Responsible Editor: M. Francis and K. Weng.

BD Bruce is retired from CSIRO Oceans and Atmosphere Organisation.

Russell Bradford

Russ.Bradford@csiro.au

1 CSIRO Oceans and Atmosphere, Hobart, TAS 7001, Australia

2 South Australian Research and Development Institute (Aquatic Sciences), West Beach, Adelaide, SA 5024, Australia

3 The Minderoo Foundation, Broadway, Nedlands, WA 6009, Australia anthropogenic activities and underlies the structuring of suitable conservation and management approaches to populations that have undergone historical declines or are conservation dependent (Simpfendorfer et al. 2010). Additionally, understanding the behavioural response to variable environments over a range of spatial and temporal scales may also be fundamental to evaluating the habitat requirements of populations. White sharks, Carcharodon carcharias, are large, circum-globally distributed marine apex predators that inhabit temperate and sub-tropical waters (Compagno 2001). In common with other elasmobranchs, white sharks

4 University of Western Australia, 35 Stirling Hwy, Crawley, WA 6009, Australia

5 Department of Primary Industries and Regional Development (Marine Operations Centre), South Fremantle, WA 6162, Australia

6 College of Science and Engineering, Flinders University, Bedford Park, Adelaide, SA 5042, Australia

7 Fox Shark Research Foundation, Joslin, Adelaide, SA 5070, Australia 
display several $K$-selected life history traits that when combined, characterise populations as potentially sensitive to the impacts of some marine activities, including incidental bycatch in fisheries, trophy hunting to remove body parts (e.g. jaws and teeth), as well as ecosystem-level impacts on key prey and habitats, e.g. potential changes of vertical and horizontal thermal habitats driven by climate change.

Perceived worldwide declines in white shark populations have resulted in protection of the species under various international (Appendix II of Convention on International Trade in Endangered Species (CITES) [2005] and Appendix I and II of the Convention on the Conservation of Migratory Species (CMS) [2010]) and national legal instruments (e.g. Environment Protection and Biodiversity Conservation Act 1999 (EPBC Act), Australia). In Australia, the species is listed as 'vulnerable' under the Australian EPBC Act (1999) and as such, is subject to a recovery plan aimed at rebuilding the population. The species is also protected by State fisheries legislation across the southern Australian range. The adult component of the southern-western Australian (SWA) population was recently estimated to be approx. 1460 (range 760-2250) (Bruce et al. 2018). However, to accurately assess and monitor the status of highly migratory species, such as the white shark, it is important to understand ontogenically-related movement patterns to distinguish shifts in distribution from apparent changes in population structure and abundance.

In Australia, white sharks are broadly distributed throughout southern waters from North West Cape, Western Australia to southern Queensland (Last and Stevens 2009). Previous white shark tagging studies in Australia have indicated most movement patterns are restricted to coastal, continental shelf or slope waters (Malcolm et al. 2001 (five tags), Bruce et al. 2006 (six tags), Bruce and Bradford 2012 (21 tags)), with limited movement between Australia and New Zealand. Research in New Zealand, on the other hand, has demonstrated more wide-spread movements across ocean basins between New Zealand, tropical Pacific islands and Australia (Duffy et al. 2012). However, this remains at odds with movement patterns by this species in other areas of the world, where white sharks have been found to regularly exhibit offshore migratory movements and have spent as long as 1.5 years in areas of open ocean that were located several thousands of kilometres from the coast. Examples of oceanic behavioural stages include migrations by white shark in the southwest (Bonfil et al. 2010) and northeast Pacific Ocean (Nasby-Lucas et al. 2009) and the northern Atlantic Ocean (Skomal et al. 2017).

Most tagging and satellite-based tracking of white sharks in Australia, has focussed on juvenile and smaller sub-adult sharks in eastern Australia (1.8-3.2 m) and a smaller number of larger sub-adults $(<3.8 \mathrm{~m})$ in South and Western Australia with relatively few adults tagged. These studies have demonstrated that movements of white sharks are restricted in their east-west connectivity, leading to a two population model for the Australasian region which is supported by genetic analyses, acoustic telemetry studies (Blower et al. 2012; McAuley et al. 2017) and recent genetic assessments of kinship throughout Australia and New Zealand (Hillary et al. 2018). The two populations are separated east and west by Bass Strait with New Zealand and the southwest Pacific forming part of the eastern Australasian population (Bruce and Bradford 2012; Duffy et al. 2012; Francis et al. 2012). This study focusses on the movements and habitat use of the SWA white shark population as there is greater uncertainty regarding the ecology of the SWA population of white sharks than for the eastern population. In response, we compiled available tracking data to examine how the distribution of SWA white sharks relates to broad scale habitat features, such as depth, distance to the coastline and related habitat quantities.

Previous studies (Malcolm et al. 2001; Bruce et al. 2005; Robbins and Booth 2012; Bruce and Bradford 2015; Rogers and Huveneers 2016) have documented aggregation sites, such as the Neptune Islands in South Australia which also contains Australia's largest pinniped colonies (Shaughnessy and McKeown 2002). Visits by white sharks to the Neptune Islands show a distinctive seasonal pattern that varies between sexes with females, including adults, visiting the site almost exclusively during winter, whereas males tend to visit all year round (Bruce and Bradford 2015). This led these authors to propose that white sharks in southern Australia are likely to show seasonal- and sex-specific differences in their distribution and movement patterns. Accounting for differences in movement patterns provides input into identifying potential risks of human-shark interactions and effective conservation management policy.

We used satellite telemetry data collected from tags deployed on juvenile, sub-adult and adult white sharks to examine: (1) sex-specific distribution patterns within the SWA population; (2) seasonal movements of sub-adult and adults, including the extended periods of open ocean travel, as observed for white shark populations in other ocean basins and (3) evidence of the location(s) of nursery/pupping areas based on the movements of adult females.

\section{Methods}

Electronic tags were deployed on white sharks at three locations across southern Australia from the Doubtful Islands (eight tags) in Western Australia $\left(34.37^{\circ} \mathrm{S}, 119.61^{\circ} \mathrm{E}\right)$ to the lower Eyre Peninsula in South Australia (Fig. 1). The majority of tags were deployed within the Neptune Islands Group (Ron and Valerie Taylor) Marine Park, located approx. $60 \mathrm{~km}$ south of Port Lincoln, South Australia: 11 tags at 
Fig. 1 Study region with tagging locations marked for Western Australia and South Australia. GAB Great Australian Bight

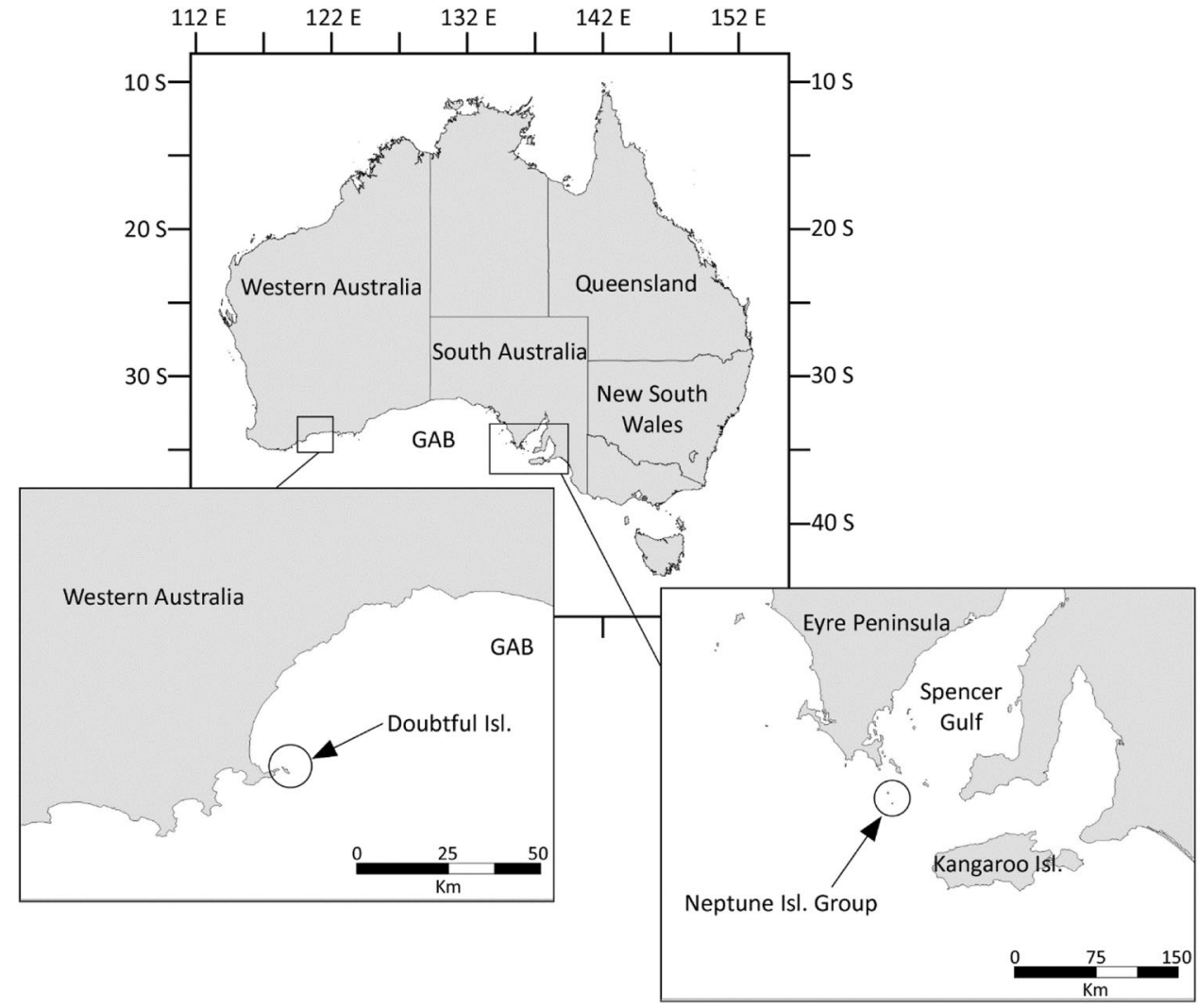

South Neptune Islands $\left(35.33^{\circ} \mathrm{S}, 136.12^{\circ} \mathrm{E}\right) ; 24$ tags at North Neptune Islands $\left(35.23^{\circ} \mathrm{S}, 136.07^{\circ} \mathrm{E}\right)$.

Tags were deployed over a 15-year period between 2003 and 2017 (Table 1) in a range of projects; the tracking data have been compiled for this project. Pop-up satellite-linked archival tags (PSATs) were typically configured with a tether that consisted of $150-250 \mathrm{~mm}$ of $180 \mathrm{~kg}$ monofilament or plastic coated $2 \mathrm{~mm}$ stainless steel multi-strand wire, terminating in either a plastic umbrella style anchor or a titanium textured anchor. PSATs were deployed on free-swimming white sharks attracted to the vessel using a mixture of minced tuna parts, tuna oil and fish blood (berley). Once sharks were attracted to the vessel a teaser bait (large portion of tuna) was used to draw the shark to the rear of the vessel and close enough to apply the tag using a tagging pole.

All PSATs were programmed to release after periods from 30 to 180 days after deployment and transmit their summarized data through the Argos constellation of satellites (www.argos-system.org). Each tag was programmed to collect ambient light levels, temperature and depth, typically at $10 \mathrm{~s}$ intervals and pooled into $6 \mathrm{~h}$ bins for transmission.

Satellite-linked radio tags (SLRTs) were physically attached to the first dorsal fin of sharks which were caught and temporarily restrained beside the vessel in a purposebuilt in-water stretcher as described in Bruce et al. (2006) and Bruce and Bradford (2013a). Sharks were attracted to the tagging vessel using berley, where they were presented with a baited hook on a $1.2-1.5 \mathrm{~m}$ stainless steel wire rope (4-6 mm diameter) leader attached to a $12 \mathrm{~mm}$ silver nylon rope. On taking the bait, the hook was set and one or more $30 \mathrm{~cm}$ floats attached to the line. The shark was allowed to tire itself against the resistance of the float before being guided into the in-water stretcher. Upon restraint an oxygenated flow of seawater was provided to irrigate the gills. Once the SLRT was attached, the hook was removed and the shark guided out of the stretcher. Typically, a shark would be restrained for no longer than $10 \mathrm{~min}$.

Near-real time position data were available for sharks fitted with SLRTs. These tags transmitted summarised data to the Argos system whenever they were exposed to air and the position of the tag was estimated using a Doppler shift algorithm (www.argos-system.org). Position estimates were provided in seven location quality classes (LC) ranging from the lowest to the highest predicted root mean square errors of: LC-3 $\leq 250 \mathrm{~m}, \mathrm{LC}-2$ 250-500 m, LC-1 500-1500 m. Location classes LC-0, LC-A, LC-B have predicted root mean square errors of $>1500 \mathrm{~m}$ and $\mathrm{LC}-\mathrm{Z}$ has no position. Extreme outliers (those indicating unrealistic swimming speeds well in excess of $5 \mathrm{kph}$ ), positions on land and those with unclassified error estimates (LC-Z) were removed. The data from all Wildlife Computer pop-off satellite archival tags (PSAT) were processed through the Wildlife Computers Portal (www.wildlifecomputers.com); one shark was fitted with a Microwave Telemetry PSAT tag; position data were 
Table 1 Satellite tag deployment details

\begin{tabular}{|c|c|c|c|c|c|c|c|c|}
\hline Fish ID & Length (m) & Release region & Deploy date & Pop-up date & Track days & Track length (km) & $\begin{array}{l}\text { Daily dis- } \\
\text { tance }(\mathrm{km})\end{array}$ & Tag type \\
\hline WSM-01 & 3.8 & N Nept & $31 / 12 / 15$ & 23/01/16 & 23 & 971 & 42 & WC PSAT \\
\hline WSF-02 & 5.0 & S Nept & $15 / 07 / 14$ & $27 / 08 / 14$ & 42 & 2355 & 56 & WC PSAT \\
\hline WSF-03 & 4.8 & N Nept & $07 / 02 / 16$ & $06 / 07 / 16$ & 149 & 12,220 & 82 & WC PSAT \\
\hline WSF-04 & 3.8 & N Nept & $23 / 07 / 15$ & $01 / 08 / 15$ & 8 & 308 & 39 & WC PSAT \\
\hline WSF-05 & 4.6 & N Nept & $06 / 08 / 15$ & $05 / 11 / 15$ & 89 & 6467 & 73 & WC PSAT \\
\hline WSM-06 & 3.1 & N Nept & $15 / 06 / 16$ & $13 / 10 / 16$ & 120 & 4813 & 40 & WC PSAT \\
\hline WSF-07 & 4.3 & S Nept & $25 / 07 / 15$ & $22 / 11 / 15$ & 117 & 2641 & 23 & WC PSAT \\
\hline WSM-08 & 4.0 & S Nept & $25 / 07 / 15$ & $28 / 07 / 15$ & 3 & 74 & 25 & WC PSAT \\
\hline WSM-09 & 4.2 & N Nept & $25 / 01 / 16$ & $24 / 05 / 16$ & 119 & 4184 & 35 & WC PSAT \\
\hline WSM-10 & 2.7 & N Nept & $26 / 07 / 15$ & $29 / 07 / 15$ & 3 & 68 & 23 & WC PSAT \\
\hline WSM-11 & 3.2 & N Nept & $26 / 07 / 15$ & $29 / 07 / 15$ & 3 & 75 & 25 & WC PSAT \\
\hline WSM-12 & 3.6 & N Nept & $17 / 12 / 15$ & $10 / 01 / 16$ & 23 & 1200 & 52 & WC PSAT \\
\hline WSM-13 & $?$ & N Nept & 07/10/12 & $06 / 03 / 13$ & 149 & 7028 & 47 & WC PSAT \\
\hline WSF-14 & 5.7 & S Nept & $15 / 06 / 13$ & $07 / 10 / 13$ & 112 & 5834 & 52 & WC PSAT \\
\hline WSF-15 & 3.5 & Doubtful Isl & $04 / 05 / 03$ & 06/07/03 & 62 & & & WC PSAT \\
\hline WSF-16 & 3.0 & Doubtful Isl & $04 / 10 / 03$ & $25 / 11 / 03$ & 51 & 4085 & 80 & WC PSAT \\
\hline WSM-17 & 4.0 & N Nept & $29 / 11 / 12$ & $29 / 12 / 12$ & 30 & 1192 & 40 & WC PSAT \\
\hline WSM-18 & 3.5 & N Nept & $29 / 11 / 12$ & $30 / 11 / 12$ & 1 & & & WC PSAT \\
\hline WSF-19 & 2.8 & Doubtful Isl & $04 / 10 / 03$ & $29 / 01 / 04$ & 117 & 1683 & 14 & MWT PSAT \\
\hline WSM-20 & 3.8 & N Nept & $10 / 11 / 04$ & $09 / 05 / 05$ & 179 & 3256 & 18 & WC PSAT \\
\hline WSM-21 & 3.2 & N Nept & $12 / 11 / 04$ & $04 / 05 / 05$ & 172 & 3088 & 18 & WC PSAT \\
\hline WSM-22 & 4.2 & N Nept & $23 / 05 / 08$ & $11 / 07 / 08$ & 48 & 2219 & 46 & WC PSAT \\
\hline WSU-23 & 3.5 & N Nept & $23 / 05 / 08$ & $27 / 05 / 08$ & 4 & 241 & 60 & WC PSAT \\
\hline WSF-24 & 4.2 & S Nept & $02 / 05 / 15$ & $10 / 08 / 15$ & 98 & 2711 & 28 & WC PSAT \\
\hline WSF-25 & 2.2 & S Nept & $06 / 05 / 15$ & $09 / 07 / 15$ & 63 & 2546 & 40 & WC PSAT \\
\hline WSF-26 & 3.0 & S Nept & $06 / 05 / 15$ & $14 / 08 / 15$ & 98 & 4447 & 45 & WC PSAT \\
\hline WSF-27 & 4.2 & S Nept & $06 / 05 / 15$ & $14 / 08 / 15$ & 98 & 1715 & 18 & WC PSAT \\
\hline WSM-28 & 3.3 & S Nept & $02 / 05 / 15$ & $10 / 08 / 15$ & 98 & 5217 & 53 & WC PSAT \\
\hline WSF-29 & 5.2 & S Nept & $15 / 07 / 14$ & & & 2313 & & WC PSAT* \\
\hline WSM-30 & 3.2 & N Nept & $27 / 07 / 16$ & $24 / 12 / 16$ & 147 & 2314 & 16 & WC PSAT* \\
\hline WSM-31 & 2.1 & Doubtful Isl & $17 / 08 / 14$ & $09 / 10 / 14$ & 52 & & & WC PSAT \\
\hline WSF-32 & 5.2 & S Nept & $19 / 04 / 14$ & $17 / 09 / 14^{\mathrm{F}}$ & 22 & 573 & 26 & WC PSAT \\
\hline WSM-33 & 3.2 & N Nept & $11 / 11 / 04$ & & 365 & 3372 & 9 & WC SLRT \\
\hline WSM-34 & 3.2 & N Nept & $13 / 11 / 04$ & & 92 & 2438 & 27 & WC SLRT \\
\hline WSF-35 & 3.5 & N Nept & $29 / 06 / 06$ & & 381 & 7501 & 220 & WC SLRT \\
\hline WSF-36 & 3.0 & Doubtful Isl & $05 / 10 / 03$ & & & & & ST SLRT \\
\hline WSU-37 & $?$ & Doubtful Isl & 06/10/03 & & & & & ST SLRT \\
\hline WSU-38 & $?$ & Doubtful Isl & $06 / 10 / 03$ & & & & & ST SLRT \\
\hline WSM-39 & 3.6 & N Nept & $30 / 03 / 04$ & & 162 & 4031 & 25 & ST SLRT \\
\hline WSF-40 & 3.3 & N Nept & $01 / 04 / 04$ & & 147 & 3205 & 22 & ST SLRT \\
\hline WSM-41 & 3.8 & N Nept & $10 / 11 / 04$ & & 19 & 635 & 33 & ST SLRT \\
\hline WSM-42 & 3.2 & N Nept & $12 / 11 / 04$ & & 173 & 1803 & 10 & ST SLRT \\
\hline WSF-43 & 5.1 & Doubtful Isl & $16 / 11 / 17$ & $10 / 12 / 17$ & 24 & 1103 & 46 & WC PSAT \\
\hline
\end{tabular}

$M$ male, $F$ female, $U$ unknown sex. All length measurements are reported as total length. $N$ Nept North Neptune Island, $S$ Nept South Neptune Island. Date format is DD/MM/YY. Tag manufacturer is denoted as: WC Wildlife Computers; MWT Microwave Telemetry; ST Sirtrack

* = no sensor data available. ${ }^{\mathrm{T}}$ data only available for 22 days between 16 June 2014 and 09 July 2014 
provided by Microwave Telemetry using their proprietary software. All position data were mapped using MapInfo GIS (version 7.5) software.

The total distance travelled was estimated using the ConnectTheDots tool within the MapInfo software package. Average daily displacement was then calculated by dividing the total distance travelled by the number of days at liberty, which for PSAT tags was the difference between deployment date and pop-up date and for SLRT tags was the difference between deployment date and the date of the last transmission.

To obtain the depth of ocean at a given point on the shark's track, ETOPO1 bathymetry (Amante and Eakins, 2009) was queried via the R package "marmap" (Pante and Simon-Bouhet, 2013). This package was also used to calculate the distance from a point on the shark's track to the 200 and $0 \mathrm{~m}$ isobaths. Distance to the Neptune Islands $\left(136.1184^{\circ} \mathrm{E}, 35.3174^{\circ} \mathrm{S}\right)$ was estimated as the great circle distance from each point. This distance (which does not account for the need to swim around land masses) was used as a proxy in the analysis as opposed to calculating the total distance a shark would need to travel when estimating energy expenditure, for example. All data summaries and statistical analysis used R 3.6.1 (R Core Team, 2019).

\section{Results}

A total of 43 electronic tags were deployed on white sharks, consisting of 33 pop-up satellite archival tags (PSAT) and ten satellite-linked radio tags (SLRT). All tags were deployed between May 2003 and November 2017. The total lengths (TL) of tagged sharks ranged between 1.9 and $5.7 \mathrm{~m}$. Males measured from 1.9 to $4.2 \mathrm{~m} \mathrm{TL}(n=21)$, females measured from 2.2 to $5.7 \mathrm{~m}$ TL $(n=19)$, with three sharks of unknown sex, two of which were of unknown length (Table 1).

Satellite tags provided 3663 days of tracking data covering a total distance in excess of $109,900 \mathrm{~km}$. The number of estimated satellite positions from PSATs was 8420 and the number of Argos estimated positions from the SLRTs was 1952. Few PSAT tags remained attached for the entire programmed time ( $\sim 40 \%)$ and four PSAT tags failed to transmit any data. The successful PSATs remained attached for periods ranging from 1 to 179 days. There was no statistical difference (Welch 2-sample $t$ test, $t=0.154, \mathrm{df}=35, p=0.878$ ) in the number of days tags were attached between male and female white sharks.

Movement patterns indicated long-distance dispersal of individuals, with the majority of tracks $(n=29)$ each exceeding an estimated $1000 \mathrm{~km}$ in length (Fig. 2). Male white sharks moved throughout southern waters, covered a longitudinal range of $\sim 4000 \mathrm{~km}\left(112^{\circ} \mathrm{E}-154^{\circ} \mathrm{E}\right)$ and an average track length of $\sim 2525 \pm 457 \mathrm{~km}( \pm \mathrm{SE})$. Tracks of male sharks were confined to southern waters between $22.5^{\circ} \mathrm{S}$ and $42^{\circ} \mathrm{S}$. Female white sharks covered broader longitudinal ranges $\left(\sim 4300 \mathrm{~km}: 104^{\circ} \mathrm{E}-161^{\circ} \mathrm{E}\right)$ than males. The average track length of female white sharks was $\sim 3630 \pm 705 \mathrm{~km}$. Tracks of females spanned latitudes between $21^{\circ} \mathrm{S}$ and $55^{\circ} \mathrm{S}$. There was no statistical difference (Welch 2-sample $t$ test, $t=1.298, \mathrm{df}=27, p=0.205)$ in the overall length of tracks between male and female white sharks. In addition, when standardising tracks to daily displacement (distance/days at liberty) there was no statistical difference (Welch 2-sample $t$ test, $t=1.833, \mathrm{df}=16.97, p=0.084$ ) in daily displacement between male and female white sharks.

Male white sharks mostly remained within shelf waters in depths $<100 \mathrm{~m}$. One male shark (WSM-20) indicated a brief period in off-shelf waters to the south of the mid-Great Australian Bight. Female white sharks also spent a high proportion of time in shelf waters, but included more time in off-shelf waters with occasional dives to depths $>1000 \mathrm{~m}$.

Although in off-shelf waters, all females spent time over zones of major bathymetric relief. For example, one subadult female (WSF-5, $4.6 \mathrm{~m} \mathrm{TL}$ ) followed the shelf slope edge westwards from the Neptune Islands to the Recherche Archipelago off Western Australia between 19 August 2015 and 30 September 2015 (Austral winter/spring) before turning south and travelling $\sim 1700 \mathrm{~km}$ further to intersect with the Heemskerk Fracture Zone (Fig. 2). At this point (19 October 2015) the shark continued in a westerly direction parallel to the Southeast Indian Ridge for $\sim 1000 \mathrm{~km}$ before the tag detached.

A second adult female (WSF-3, $4.8 \mathrm{~m} \mathrm{TL}$ ) travelled over an estimated distance of $\sim 12,240 \mathrm{~km}$, moving eastwards from South Australia into the central Tasman Sea between 14 January 2016 and 6 March 2016 (Austral summer) before heading south to sub-Antarctic waters off Macquarie Island $\left(55.03^{\circ} \mathrm{S}\right.$ and $\sim 2700 \mathrm{~km}$ south of tagging location, 29 March 2016). After reaching Macquarie Island, the shark returned to the region of tagging in mid May 2016 spending $~ 17$ days over and near the Ninene Trough before following the shelf edge westward for a further $2000 \mathrm{~km}$ before the tag detached in June 2016.

Profiles of the sea surface temperature (SST) experienced by female (median $=15.5^{\circ} \mathrm{C}$ ) and male $\left(17.8^{\circ} \mathrm{C}\right)$ white sharks between the latitudes of $30^{\circ} \mathrm{S}$ and $45^{\circ} \mathrm{S}$ indicated that female white sharks experienced slightly cooler SST (Fig. 3a). The data from latitudes further south than $45^{\circ} \mathrm{S}$ were removed to avoid the possibility of skewing the data on sea surface temperature experience.

From February through August (Austral late summer, autumn and winter) female white sharks consistently occupied waters with a lower sea surface temperature than males (Fig. 3b). In the Austral spring, however, (September-October) female white sharks tended to occupy waters with a higher SST than males. Unfortunately, there are no 


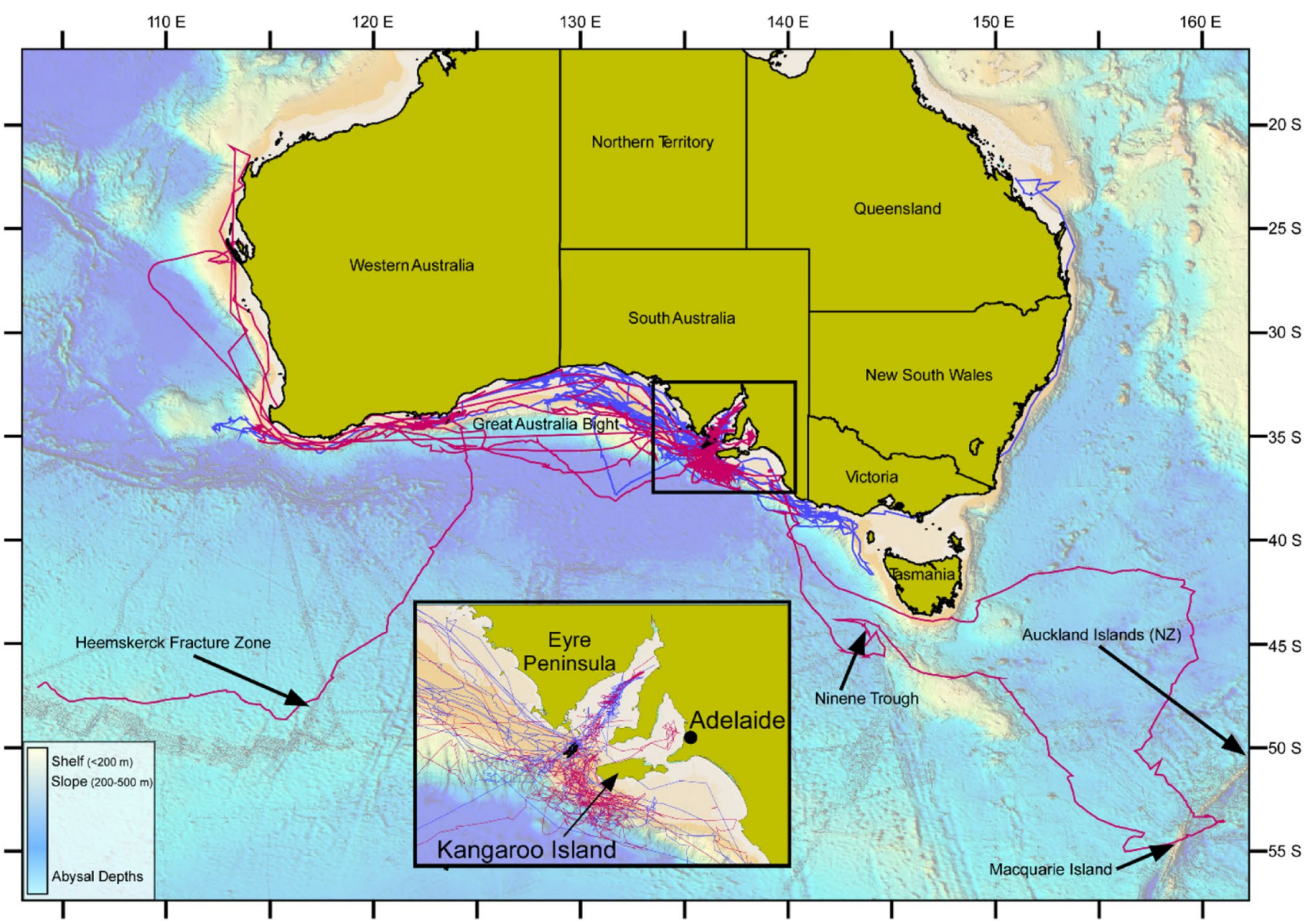

Fig. 2 Combined tracks of white sharks, Carcharodon carcharias, tagged in south-western Australian waters with female sharks in red, male sharks in blue and sharks of unknown sex in black. Insert provides greater detail where there is a high degree of overlapping tracks. A coloured digital elevation model illustrates the bathymetry of the study region
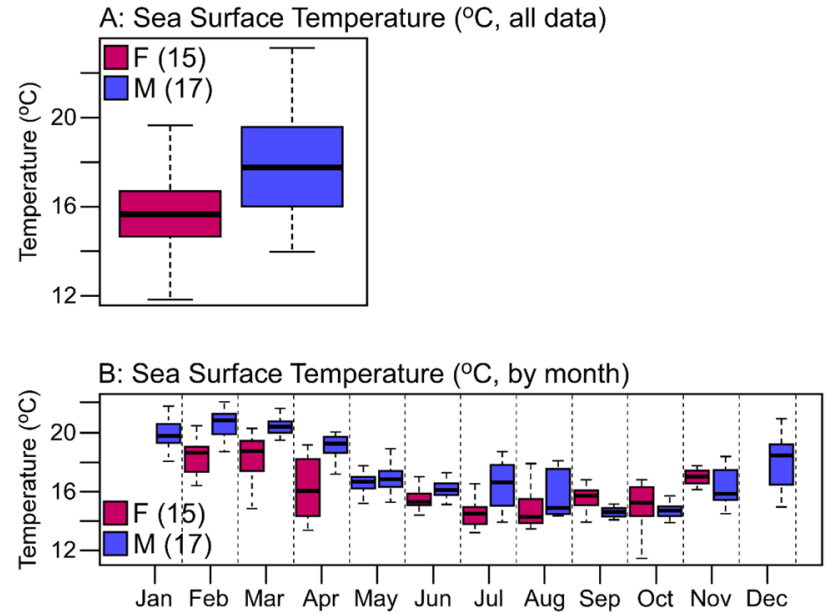

Fig. 3 a Sea surface temperature $\left({ }^{\circ} \mathrm{C}\right)$ profile for all data points grouped by sex (n); b Sea surface temperature $\left({ }^{\circ} \mathrm{C}\right)$ experiences of all sharks grouped by month and sex. All box plots indicate the median (solid horizontal line within the box), the box indicates the sample median (solid line) and the whiskers indicating the extent of the first and third quartile temperature data for female white sharks for the months of December and January.

Male white sharks spent more time in shelf waters (Fig. 2), with the distance to the $200 \mathrm{~m}$ isobath (shelf break) greatest in the head of the Great Australian Bight (GAB, Fig. 4a). When the outliers are excluded, female white sharks tended to remain closer to the $200 \mathrm{~m}$ isobath (Fig. 4a). During the late Austral autumn/winter period both sexes aggregated in the vicinity of the Neptune Islands (Fig. 4b). No data, including immediately following tagging, were excluded in this analysis of broad seasonal patterns.

In the upper $200 \mathrm{~m}$ of the water column, there was no difference in the proportion of time either sex spent at depth (Fig. 5a); with both sexes spending the majority of their time in the upper $50 \mathrm{~m}$. For male white sharks, the total proportion of time spent in warmer water was greater than that for females (Fig. 5b). This appears to be driven by the amount of time males spend in shelf waters of the upper GAB, as illustrated by the extended right tail of Fig. 5b. 

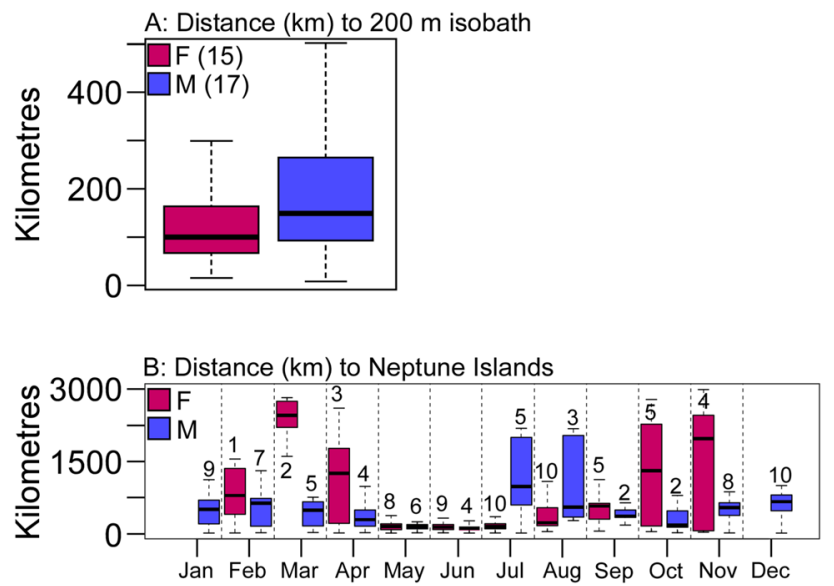

Fig. 4 a Distance $(\mathrm{km})$ of position estimates to the $200 \mathrm{~m}$ isobath for all sharks grouped by sex $(\mathrm{n})$; b distance $(\mathrm{km})$ of position estimates to the Neptune Islands, South Australia grouped by sex. All box plots indicate the median (solid horizontal line within the box), the box indicates the sample median (solid line) and the whiskers indicating the extent of the first and third quartile

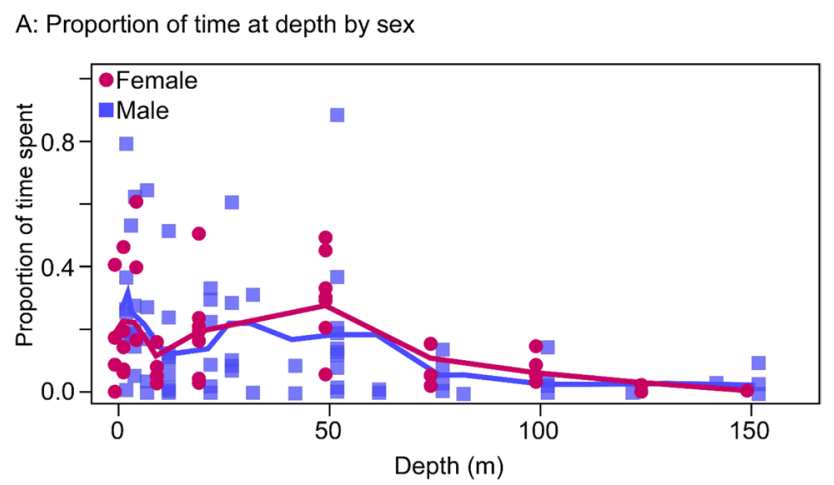

B: Proportion of time at temperature by sex.

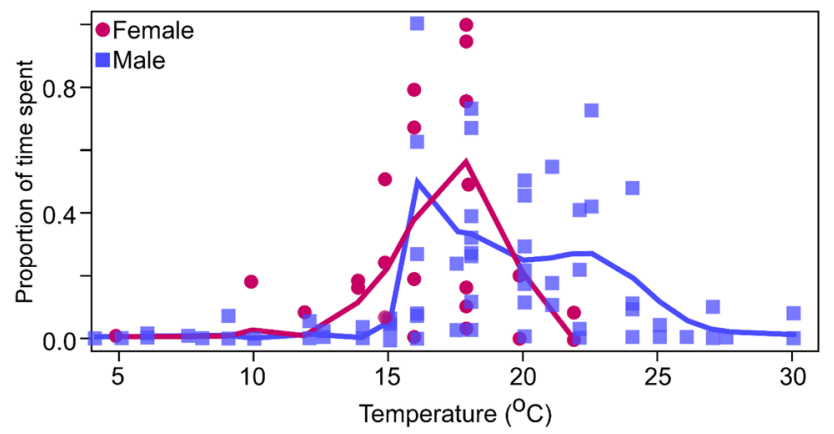

Fig. 5 a Proportion of time spent at depth (m) for all sharks grouped by sex with female sharks in red, male sharks in blue; $\mathbf{b}$ Proportion of time spent at temperature $\left({ }^{\circ} \mathrm{C}\right)$ for all sharks grouped by sex. The line through the data is a Friedman's super smoother implemented in the R function "supsmu” (Friedman 1984)

Pop-up archival transmitting tag data demonstrated that white sharks of both sexes experienced a wide temperature range (females $9.0-19.0^{\circ} \mathrm{C}$; males $10.4-24.8^{\circ} \mathrm{C}$ ) with a high degree of overlap between the sexes. The PSAT data also demonstrated that white sharks spent $50 \%$ of their time in waters $\leq 200 \mathrm{~m}$ depth. Looking more closely at the temperature data for when white sharks are in depths $\leq 200 \mathrm{~m}$ there was a tendency for females to spend more time in cooler waters, as well as displaying a distinctive two-peak profile (Fig. 6). Males, on the other hand, tended to spend more time in warmer waters and displayed a broader profile in overall temperature experience.

\section{Discussion}

This study provides new evidence of diverse on-shelf and off-shelf oceanic movements and expansive depth and thermal habitat use by the SWA population of white sharks in the South-east Indian Ocean. Satellite tagging conducted over 15 years showed white sharks ranged widely throughout southern Australia, with subtle differences in the dispersal patterns of males and females. A feature differentiating this dataset from previous studies of the SWA population (Bruce et al. 2006) is the extended offshore movements by two individuals WSF-03 and WSF-05, including the expansive oceanic transits into sub-Antarctic waters. Potential explanations of oceanic transits have been the subject of several studies in the Northern Hemisphere (Pacific Ocean), yet telemetry technologies applied to pelagic sharks limit the ability to directly link observed datasets to ecological variables. New configurations of equipment incorporating telemetry devices, accelerometers and cameras are currently being trialled to uncover the motivating factors for these oceanic transits.

In light of the globally high public profile of white sharks, efforts to study and understand their basic life history and ecology, such as their movements and the extent to which they use the environments through which they move, have increased. Previously, white sharks in the Australian region had been characterised predominantly as shelf inhabitants (Bruce et al. 2006; McAuley et al. 2017). However, the recent evidence has identified some white sharks in this

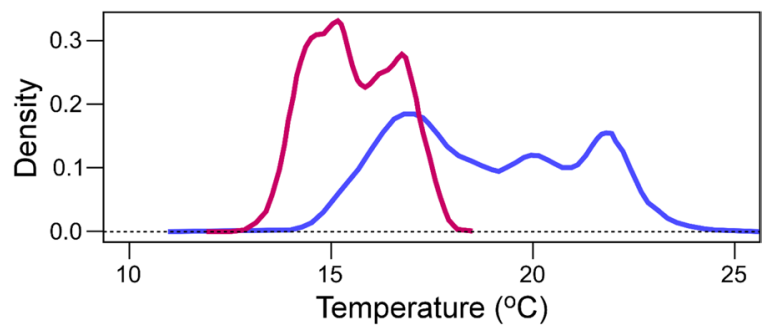

Fig. 6 Density plot of temperature $\left({ }^{\circ} \mathrm{C}\right)$ data points for all pop-up archival transmitting tags (PSAT) grouped by sex with female sharks in red, male sharks in blue 
region making extended oceanic excursions and crossing ocean basins (Bruce et al. 2006; Bonfil et al. 2010; Bruce and Bradford 2012; Duffy et al. 2012). This study has demonstrated that within the SWA white shark population the use of off-shelf and slope waters is greater than previously thought; however, female white sharks may make greater use of off-shelf waters than their male counterparts.

Excursions into the higher latitudes in both the southern (off-shelf) and northern (on-shelf) hemispheres have previously been recorded. For example, Francis et al. (2012) tracked a $4.4 \mathrm{~m}$ female white shark that travelled $\sim 450 \mathrm{~km}$ south of New Zealand to the vicinity of the Auckland Islands $\left(50.7^{\circ} \mathrm{S}\right)$ and reported sightings of white sharks at the Campbell Islands $\left(52.6^{\circ} \mathrm{S}, 169.2^{\circ} \mathrm{E}\right), \sim 650 \mathrm{~km}$ south of New Zealand. In the North-west Pacific white sharks have been recorded from waters of $\sim 46.5^{\circ} \mathrm{N}$ (Christiansen et al. 2014), in the North-east Pacific from $60.3^{\circ} \mathrm{N}$ (Martin 2004; COSEWIC 2006) and in the North-west Atlantic as far north as $\sim 51.3^{\circ} \mathrm{N}$ (COSEWIC 2006).

Based on the existing literature and the present study, no conclusions can be drawn with respect to the distribution of sexes at the northern and southern extremes of the white sharks' range. Observations of both sexes have been recorded at the extremes of their distribution. In the Northwest Pacific, the most northern observation was of a male white shark (Christiansen et al. 2014). In the North-east Pacific a $6 \mathrm{~m}$ white shark was recorded at $\sim 59.5^{\circ} \mathrm{N}$, however, sex was not recorded (Martin 2004). While in the Northwest Atlantic very few reports contained the sex of the animal observed (COSEWIC 2006). In the southern hemisphere, both Francis et al. (2012) and the present study have observed female white sharks at the most southern extremes, suggesting mature females may roam more widely and experience greater fluctuations in temperature.

White sharks WSF-3 and WSF-5 both made extensive excursions into off-shelf waters where at times there appeared to be an affinity to major bathymetric features such as the Ninene Trough and Heemskerk fracture zone. Francis et al. (2012) also noted an association between the tracks of white sharks and bathymetric features such as the Solandar Trough. Further, Domeier (2012) reported on a sub-adult male white shark that criss-crossed a fracture zone in the mid-Pacific during an extended offshore migration towards the Hawaiian Islands and the Shared Offshore Foraging Area (SOFA). Fracture zones represent regions of high magnetic anomaly against a background of bands of highs and lows parallel to the axis of mid-oceanic ridges (Kirschvink et al. 1986). Although the mechanisms by which animals detect and process the earth's magnetic field are poorly understood, there are examples from all classes of vertebrates indicating a capacity to use the earth's magnetic field to guide their long-distance migrations (Lohmann and Johnsen 2000). Evidence exists that several shark species use the earth's magnetic field for navigational purposes (Carey and Scharold 1990; Holland et al. 1999; Meyer et al. 2005). For example, Klimley (1993) found the movements of scalloped hammerhead sharks (Sphyrna lewini) were guided by anomalies in the earth's magnetic field as they moved between a seamount and their pelagic foraging areas. Hammerhead sharks appeared to be using local maxima and minima in the geomagnetic field as movement corridors when in the pelagic environment, with the strong dipole magnetic field around the seamount serving as a beacon facilitating their return (Klimley 1993). Kirschvink et al. (1986) postulated that marine animals may seek geomagnetic minima during periods of migration, while using geomagnetic highs to pinpoint foraging areas such as marine canyons and seamounts. While the data in this study are restricted to two notable examples of off-shelf movements and the association with major bathymetric features is striking, the reasons for this association by SWA white sharks are unknown.

Australia's continental shelf has $\sim 423$ submarine canyons (Heap and Harris 2008), with the southeastern coastline having the largest concentration and coverage of Australia's marine canyon systems (Huang et al. 2014). Most are located along the lower shelf/upper slope (Huang et al. 2014; Conlan et al. 2015) and are characterised by valleys, plateaus and ridges supporting upwelling, downwelling and other current-driven processes (Middleton and Cerano 2002; Middleton and Bye 2007). Combinations of productive demersal communities (Williams et al. 2001; Currie and Sorokin, 2014) and fluctuations in pelagic production (McClatchie et al. 2006) along these shelf edges may partly explain the use of these canyon habitats by a range of migratory marine predator species, including white sharks. The majority of the tracks of male and female white sharks in this study indicated varying degrees of fidelity to the lower shelf/upper slope systems. The recent findings have found the shelf-incising Murray Canyons Group (Schmidt et al. 2010) located south of Kangaroo Island to support high concentrations of southern bluefin tuna (Thunnus maccoyii) which are thought to be linked to high densities of sardine (Sardinops sagax), Australian anchovy (Engraulis australis) and other small pelagic prey present in the region (Conlan et al. 2015). Field observations during pelagic surveys have also identified large aggregations of pinnipeds, cetaceans and other species of pelagic sharks at the head of the du Couedic Canyon south of Kangaroo Island (Rogers et al. 2016). The southern and western coasts of Kangaroo Island and the Neptune Islands Group have significant pinniped colonies (Shaughnessy et al. 2011) that may form stop-off points for white sharks as they migrate to and from on-shelf and off-shelf oceanic regions. Future studies could investigate the significance of these offshore canyon habitats in terms of the relative residency of white sharks in these as compared to other marine protected areas. 
In this study, observed off-shelf excursions were mainly, but not exclusively, restricted to female white sharks. Offshelf excursions by male and female white sharks are well documented within the eastern Pacific white shark population. White sharks have been tracked from the central California region to Hawaii (Boustany et al. 2002; Weng et al. 2007; Jorgensen et al. 2010); while sub-adult and adult white sharks tagged at Guadalupe Island off Mexico have been tracked to the SOFA in the central Pacific between the continental United States and Hawaii (Domeier and Nasby-Lucas 2008; Nasby-Lucas et al. 2009). In the Atlantic Ocean, a mature-sized $(5.3 \mathrm{~m})$ female travelled over $6000 \mathrm{~km}$ and occupied pelagic oceanic habitats (Skomal et al. 2017). Potential explanations for these movements have included prey searching (Domeier 2012; Duffy et al. 2012) and reproductive behaviours (Jorgensen et al. 2010, 2012). However, apart from two notable examples by mature females, all of the white sharks tracked in this study remained relatively close to the continental shelf.

In South Australia female white sharks display a highly seasonal pattern of visitation to the Neptune Islands, being present during the autumn-winter period, but largely absent from the region between August and March (Bruce and Bradford 2015; Robbins and Booth 2012). When present at the Neptune Islands, both sexes have a short residency time (mean < 11 days: Bruce and Bradford 2013b; Huveneers and Udyawer 2018); the current study supports the findings of these earlier studies. A similar seasonal aggregation of male and female white sharks during the autumn-winter period was observed by Kock et al. (2013) at a Cape fur seal colony in South Africa. Bruce and Bradford (2015) concluded that some form of sexual segregation was likely a feature of the SWA population but were unable to identify to where female white sharks dispersed after departing the Neptune Islands. It now appears that female white sharks disperse more widely and further offshore than males while generally occupying cooler waters, identifying a possible mechanism to maintain sexual segregation within this population, when sharks are absent from this important aggregation site. However, in contrast to the SWA population, sexual segregation of white sharks at Seal Island in South Africa was expressed with females dispersing to inshore areas while males were seldom detected in these inshore areas (Kock et al. 2013). Francis et al. (2015) observed a male to female sex ratio of 2.5:1 at a key white shark aggregation site off southern New Zealand. However, sexual segregation was not noted in that population, which consisted of a mix of sub-adult and adult males and sub-adult females present during late summer through early winter (Francis et al. 2015). Large female white sharks are present in New Zealand waters, including in the vicinity of the southern aggregation site, but are rarely seen or recorded (Francis 1996).
In the present study, the data were insufficient to conclusively indicate that male and female white sharks preferred different temperature regimes. However, there was a tendency for female white sharks to occupy slightly cooler waters than male white sharks. This is in contrast to the findings of Domeier and Nasby-Lucas (2012) who report female white sharks may prefer slightly warmer water than males, especially during the presumed gestation period when females remain in warmer off-shore waters. Possibly negating the advantage of warmer sea surface temperatures, female white sharks occupied a greater depth range than males leading to greater exposure to colder deep water (Domeier and Nasby-Lucas 2012). Over a much more restricted spatial scale, Robbins and Booth (2012) observed female white sharks were present at the Neptune Islands, South Australia when water temperatures were at their warmest. In a subsequent study, using a more extensive dataset, Bruce and Bradford (2015) found that the presence of female white sharks at the Neptune Islands was most likely related to differences in foraging strategies between male and female sharks and not to a difference in temperature preference.

In summary, we have identified further evidence of sexual segregation in the SWA white shark population, with female sharks tending to disperse more widely and further off-shore than their male counterparts. However their distributions overlap at key focal points during the Austral autumn-winter period, specifically the Neptune Islands and southern Australian shelf canyon systems. These regions of overlap are characterised by the presence of abundant high-energy prey species. Although both sexes undertake extensive migrations, female white sharks tended to disperse more widely and exploit off-shelf habitat to a greater extent, thus maintaining a form of sexual segregation during the Austral spring-summer period. Lastly, none of the movement data gathered provided evidence for specific regional pupping or nursery grounds. Owing to the sparse distribution and low encounter rate of adult female white sharks, further efforts to deploy satellite-linked electronic tags aimed at identifying these areas should include juvenile as well as adult female sharks.

Acknowledgements This work was primarily supported by the Marine Biodiversity Hub through the Australian Government's National Environmental Research Program (NERP) and National Environmental Science Program (NESP); R. R. and A. F. were supported by the Fox Shark Research Foundation; P. R. was supported by the South Australian Research and Development Institute (SARDI), Primary Industries and Regions (PIRSA). We thank A. Wright (Calypso Star Charters) and G. Campbell, D. Holman, D. and K. Heineke, K. Johnson, M. Sullivan, W. Austin and M. Williams, S. Madona and the Yalata Land management Group who searched the Great Australian Bight for satellite tags that had washed ashore. The manuscript greatly benefited from the comments of Richard Pillans, Emma Westlake, Malcom Francis and four anonymous reviewers. 
Funding Funding for this project was provided by the Australian Government National Environmental Science Program (NESP) Marine Biodiversity Hub (50\%) and the Commonwealth Scientific and Industrial Research Organisation (CSIRO, 50\%) for NESP Project A3: A national assessment of the status of white sharks (https://www.nespm arine.edu.au/project/project-a3-national-assessment-status-white-shark s).

Data availability The data used to produce this manuscript may be available upon request to the lead author.

\section{Compliance with ethical standards}

Conflict of interest The authors claim no conflicts of interest.

Ethical approval All tagging was carried out under permits issued by an independent animal ethics committee (Tasmanian Department of Primary Industries, Parks, Water and the Environment: AEC Permit 22/2015-16 and its predecessors) and complied with the conditions of Primary Industries and Regions South Australia Ministerial Exemption ME9902940 (and its predecessors), Department of Environment, Water and Natural Resources (DEWNR) South Australia Scientific Research permit U26255-4 (and its predecessors) and DEWNR Marine Park permit MR00025-1 (and its predecessors) allowing access to work within the Neptune Islands Group (Ron and Valerie Taylor) Marine Park. The berley used consisted of waste fish products sourced from the Australian Southern Bluefin Tuna Industry.

Open Access This article is licensed under a Creative Commons Attribution 4.0 International License, which permits use, sharing, adaptation, distribution and reproduction in any medium or format, as long as you give appropriate credit to the original author(s) and the source, provide a link to the Creative Commons licence, and indicate if changes were made. The images or other third party material in this article are included in the article's Creative Commons licence, unless indicated otherwise in a credit line to the material. If material is not included in the article's Creative Commons licence and your intended use is not permitted by statutory regulation or exceeds the permitted use, you will need to obtain permission directly from the copyright holder. To view a copy of this licence, visit http://creativecommons.org/licenses/by/4.0/.

\section{References}

Amante C, Eakins BW (2009) ETOPO1 1 Arc-Minute Global Relief Model: Procedures, Data Sources and Analysis. NOAA Technical Memorandum NESDIS NGDC-24, 19 pp https://www.ngdc.noaa. gov/mgg/global/relief/ETOPO1/docs/ETOPO1.pdf. Accessed 16 May 2018

Blower DC, Pandolfi JM, Bruce BD, del Gomez-Cabrera M, Ovenden JR (2012) Population genetics of Australian white sharks reveals fine-scale spatial structure, transoceanic dispersal events and low effective population sizes. Mar Ecol Prog Ser 455:229-244. https ://doi.org/10.3354/meps09659

Bonfil R, Francis MP, Duffy C, Manning MJ, O’Brien S (2010) Largescale tropical movements and diving behaviour of white sharks Carcharodon carcharias tagged off New Zealand. Aquatic Biol 8:115-123. https://doi.org/10.3354/ab00217

Boustany AM, Davis SF, Pyle P, Anderson SD, Le Boeuf BJ, Block BA (2002) Satellite tagging: expanded niche for white sharks. Nature 415:35-36. https://doi.org/10.1038/415035b
Bruce B, Bradford R, Bravington M, Feutry P, Grewe P, Gunasekera R, Harasti D, Hillary R, Patterson P (2018). A national assessment of the status of white sharks. National Environmental Science Programme, Marine Biodiversity Hub, CSIRO, Hobart, Tasmania. 64 pp. Available from: https://www.nespmarine.edu.au/document/ national-assessment-status-white-sharks. Accessed 9 Feb 2018

Bruce BD, Bradford RW (2012) Habitat use and spatial dynamics of juvenile white sharks, Carcharodon carcharias, in eastern Australia. In: Domeier ML (ed) Global perspectives on the biology and life history of the white shark. CRC Press, Boca Raton, pp 225-253 (ISBN: 978-1-4398-4840-1)

Bruce BD, Bradford RW (2013a) Protocols for capturing and tagging juvenile white sharks in near-shore waters. CSIRO, Australia. ISBN: 978-1-4863-0087-7. https://www.researchgate.net/publi cation/237011825_Protocols_for_capturing_and_tagging_juven ile_white_sharks_in_near-shore_waters. Accessed 15 Jan 2018

Bruce BD, Bradford RW (2013) The effects of shark cage-diving operations on the behaviour and movements of white sharks, Carcharodon carcharias, at the Neptune Islands, South Australia. Mar Biol 160:889-907. https://doi.org/10.1007/s0022 7-012-2142-z

Bruce B, Bradford R (2015) Segregation or aggregation? Sex-specific patterns in the seasonal occurrence of white sharks Carcharodon carcharias at the Neptune Islands, South Australia. J Fish Biol 87:1355-1370. https://doi.org/10.1111/jfb.12827

Bruce BD, Stevens JD, Bradford RW (2005) Site fidelity, residence times and home range patterns of white sharks around pinniped colonies. Final report to Department of Environment and Heritage. CSIRO Hobart. p 41

Bruce BD, Stevens JD, Malcolm H (2006) Movements and swimming behaviour of white sharks (Carcharodon carcharias) in Australian waters. Mar Biol 150:161-172. https://doi.org/10.1007/ s227-006-0325-1

Carey FG, Scharold JV (1990) Movements of blue sharks in depth and course. Mar Biol 106:329-342

Christiansen HM, Lin V, Tanaka S, Velikanov A, Mollet HF, Wintner SP, Fordham SV, Fisk AT, Hussey NE (2014) The last frontier: catch records of white sharks (Carcharodon carcharias) in the Northwest Pacific Ocean. PLoS ONE 9(4):e94407. https://doi. org/10.1371/journal.pone.0094407

Compagno LJV (2001) Sharks of the world. Volume 2. Bullhead, mackerel and carpet sharks (Heterodontiformes, Lamniformes, and Orectolobiformes). FAO species catalogue for fishery proposes. FAO, Rome 1:1-269

Conlan KE, Currie DR, Dittmann S, Sorokin SJ, Hendrycks E (2015) Macrofaunal patterns in and around du Couedic and Bonney submarine canyons South Australia. PLoS ONE 10(11):e0143921. https://doi.org/10.1371/journal.pone.0143921

COSEWIC 2006. COSEWIC assessment and status report on the White Shark Carcharodon carcharias (Atlantic and Pacific populations) in Canada. Committee on the Status of Endangered Wildlife in Canada. Ottawa. vii + 31 pp. (www.sararegistry.gc.ca/status/statu s_e.cfm). Accessed 25 Aug 2018

Currie DR, Sorokin SJ (2014) Megabenthic biodiversity in two contrasting submarine canyons on Australia's southern continental margin. Marine Biol Res 10:97-110. https://doi. org/10.1080/17451000.2013.797586

Domeier ML (2012) A new life-history hypothesis for white sharks, Carcharodon carcharias, in the northeastern Pacific. In: Domeier ML (ed) Global perspectives on the biology and life history of the white shark. CRC Press, Boca Raton, pp 199-223 (ISBN: 978-1-4398-4840-1)

Domeier ML, Nasby-Lucas N (2008) Migration patterns of white sharks Carcharodon carcharias tagged at Guadalupe Island, Mexico, and identification of an eastern Pacific shared offshore 
foraging area. Mar Ecol Prog Ser 370:221-237. https://doi. org/10.3354/meps07628

Domeier ML, Nasby-Lucas N (2012) Sex-specific migration patterns and sexual segregation of adult white sharks, Carcharodon carcharias, in the northeastern Pacific. In: Domeier ML (ed) Global perspectives on the biology and life history of the white shark. CRC Press, Boca Raton, pp 133-146 (ISBN: 978-1-4398-4840-1)

Duffy CAJ, Francis MP, Manning MJ, Bonfil R (2012) Regional population connectivity, oceanic habitat, and return migration revealed by satellite tagging of white sharks, Carcharodon carcharias, at New Zealand aggregation sites. In: Domeier ML (ed) Global perspectives on the biology and life history of the white shark. CRC Press, Boca Raton, pp 301-318 (ISBN: 978-1-4398-4840-1)

Francis MP (1996) Observations on a pregnant white with a review of reproductive biology. In: Klimley AP, Ainley DG (eds) Great white sharks. The biology of carcharodon carcharias. Academic Press, San Diego, CA, pp 157-172

Francis MP, Duffy CAJ, Bonfil R, Manning MJ (2012) The third dimension vertical habitat use by white sharks, Carcharodon carcharias, in New Zealand and in oceanic and tropical waters of the southwest Pacific Ocean. In: Domeier ML (ed) Global perspectives on the biology and life history of the white shark. CRC Press, Boca Raton, pp 319-342 (ISBN: 978-1-4398-4840-1)

Francis MP, Duffy C, Lyon W (2015) Spatial and temporal habitat use by white sharks (Carcharodon carcharias) at an aggregation site in southern New Zealand. Mar Freshw Res 66:900-918. https:// doi.org/10.1071/MF14186

Friedman JH (1984) A variable span scatterplot smoother. Laboratory for Computational Statistics, Stanford University Technical Report No. 5.

Heap AD, Harris PT (2008) Geomorphology of the Australian margin and adjacent seafloor. Aus J Earth Sci 55:555-585

Hillary RM, Bravington MV, Patterson TA, Grewe P, Bradford R, Feutry P, Gunasekera R, Peddemors V, Werry J, Francis MP, Duffy CAJ, Bruce BD (2018) Genetic relatedness reveals total population size of white sharks in eastern Australia and New Zealand. Sci Rep 8:2661. https://doi.org/10.1038/s41598-018-20593 $-\mathrm{W}$

Holland KN, Wetherbee BM, Lowe CG, Meyer CG (1999) Movements of tiger sharks (Galeocerdo cuvier) in coastal Hawaiian waters. Mar Biol 134:665-673. https://doi.org/10.1007/s002270050582

Huang Z, Nichol SL, Harris PT, Caley MJ (2014) Classification of submarine canyons of the Australian continental margin. Mar Geol 357:362-383. https://doi.org/10.1016/j.margeo.2014.07.007

Huveneers C, Udyawer V (2018) Residency of white sharks, Carcharodon carcharias, at the Neptune Islands Group Marine Park (2017-18). Report to the Department of Environment and Water, South Australia, p 18. https://www.environment.sa.gov.au/files/ sharedassets/marine_parks/shark_cage_diving/white-shark-neptu ne-islands-report-2018-rep.pdf. Accessed 6 Jan 2020

Jorgensen SJ, Arnoldi NS, Estess EE, Chapple TK, Rückert M, Anderson SD, Block BA (2012) Eating or meeting? Cluster analysis reveals intricacies of white shark (Carcharodon carcharias) migration and offshore behavior. PLoS ONE 7(10):e47819. https ://doi.org/10.1371/journal.pone.0047819

Jorgensen SJ, Reeb CA, Chapple TK, Anderson S, Perle C, Van Sommeran SR, Fritz-Cope C, Brown AC, Klimley AP, Block BA (2010) Philopatry and migration of Pacific white sharks. Proc Royal Society B 277:679-688. https://doi.org/10.1098/ rspb.2009.1155

Kirschvink JL, Dizon AE, Westphal JA (1986) Evidence from strandings for geomagnetic sensitivity in cetaceans. J Exp Biol 120:1-24

Klimley AP (1993) Highly directional swimming by scalloped hammerhead sharks, Sphyrna lewini, and subsurface irradiance, temperature, bathymetry, and geomagnetic field. Mar Biol 117:122. https://doi.org/10.1007/BF00346421

Kock A, O'Riain MJ, Mauff K, Meÿer M, Kotze D, Griffiths C (2013) Residency, habitat use and sexual segregation of white sharks, Carcharodon carcharias in False Bay South Africa. PLoS ONE 8:e55048. https://doi.org/10.1371/journal.pone.0055048

Last PR, Stevens JD (2009) Sharks and rays of Australia, 2nd edn. CSIRO Publishing, Collingwood, Australia (ISBN: 978-0-674-03411-2)

Lohmann KJ, Johnsen S (2000) The neurobiology of magnetoreception in vertebrate animals. Trends Neurosci 23:153-159. https://doi. org/10.1016/S0166-2236(99)01542-8

Malcolm H, Bruce BD, Stevens JD (2001) A review of the biology and status of white sharks in Australian waters. CSIRO Marine Research, Hobart, Australia, p 113

Martin A (2004) Northerly distribution of white sharks, Carcharodon carcharias, in the eastern Pacific and relation to ENSO events. Mar Fisheries Rev 66:16-26

McAuley R, Bruce B, Keay I, Mountford S, Pinnell T, Whoriskey FG (2017) Broad-scale coastal movements of white sharks off Western Australia described by passive acoustic telemetry data. Mar Freshw Res 68:1518-1531. https://doi.org/10.1071/MF16222

McClatchie S, Middleton J, Pattiaratchi C, Currie D, Kendrick G (2006) The South-west Marine Region: Ecosystems and key species groups. Report for the Department of the Environment and Water Resources

Meyer CG, Holland KN, Papastamatiou YP (2005) Sharks can detect changes in the geomagnetic field. J R Soc Interface 2:129-130. https://doi.org/10.1098/rsif.2004.0021

Middleton JF, Bye JAT (2007) A review of the shelf slope circulation along Australia's southern shelves: Cape Leeuwin to Portland. Prog Oceanogr 75:1-41

Middleton JF, Cirano M (2002) A northern boundary current along Australia's southern shelves: the Flinders current. J Geophys ResOceans 107(C9):3129-3143

Nasby-Lucas N, Dewar H, Lam CH, Goldman KJ, Domeier ML (2009) White shark offshore habitat: A behavioural and environmental characterization of the eastern Pacific shared offshore foraging area. PLoS ONE 4:e8163. https://doi.org/10.1371/journ al.pone. 0008163

Pante E, Simon-Bouhet B (2013) marmap: a package for importing, plotting and analyzing bathymetric and topographic data in R. PLoS ONE 8(9):e73051. https://doi.org/10.1371/journ al.pone. 0073051

R Core Team (2019) R: a language and environment for statistical computing. R Foundation for Statistical Computing, Vienna, Austria

Robbins RL, Booth DJ (2012) Seasonal sexual and size segregation of white sharks, Carcharodon carcharias, at the Neptune Islands, South Australia. In: Domeier ML (ed) Global perspectives on the biology and life history of the white shark. CRC Press, Boca Raton, pp 287-299 (ISBN: 978-1-4398-4840-1)

Rogers PJ, Drew M, Bailleul F, Goldsworthy SD (2016) Offshore survey of the biodiversity, distributions and habitat use of pelagic sharks in the Great Australian Bight. GABRP Research Report Number 7, Great Australian Bight Research Program, August 2016, p 77

Rogers PJ, Huveneers C (2016) Residency and photographic identification of white sharks Carcharodon carcharias in the Neptune Islands Group Marine Park between 2013 and 2015. Report to the Department of Environment, Water and Natural Resources. South Australian Research and Development Institute (Aquatic Sciences), Adelaide. SARDI Publication No. F2015/000825-1. SARDI Research Report Series No. 893. p 109 
Schmidt S, De Deckker P, Etcheber H, Caradec S (2010) Are the Murray Canyons offshore southern Australia still active for sediment transport. Geol Soc London Spec Publ 346:43-55

Shaughnessy PD, Goldsworthy SD, Hamer DJ, Page B, McIntosh RR (2011) Australian sea lions Neophoca cinerea at colonies in South Australia: distribution and abundance, 2004 to 2008. Endangered Species Res 13:87-98. https://doi.org/10.3354/esr00317

Shaughnessy PD, McKeown A (2002) trends in abundance of New Zealand fur seals, Arctocephalus forsteri, at the Neptune Islands, South Australia. Wildlife Res 29:363-370

Simpfendorfer CA, Wiley TR, Yeiser BG (2010) Improving conservation planning for an endangered sawfish using data from acoustic telemetry. Biol Cons 143:1460-1469

Skomal GB, Braun CD, Chisholm JH, Thorrold SR (2017) Movements of the white shark Carcharodon carcharias in the North Atlantic Ocean. Mar Ecol Prog Ser 580:1-16. https://doi.org/10.3354/ meps 12306
Weng KC, O’Sullivan JB, Lowe CG, Winkler CE, Dewar H, Block BA (2007) Movements, behaviour and habitat preferences of juvenile white sharks Carcharodon carcharias in the eastern Pacific. Mar Ecol Prog Ser 338:211-224. https://doi.org/10.3354/meps338211

Williams A, Koslow JA, Last PR (2001) Diversity, density and community structure of the demersal fish fauna of the continental slope off Western Australia (20 to $35^{\circ} \mathrm{S}$ ). Mar Ecol Prog Ser 212:247-263

Publisher's Note Springer Nature remains neutral with regard to jurisdictional claims in published maps and institutional affiliations. 